Jurnal e-GiGi (eG), Volume 2, Nomor 2, Juli-Desember 2014

\title{
GAMBARAN MALOKLUSI DENGAN MENGGUNAKAN HMAR PADA PASIEN DI RUMAH SAKIT GIGI DAN MULUT UNIVERSITAS SAM RATULANGI MANADO
}

\author{
${ }^{1}$ Vigni Astria Laguhi \\ ${ }^{2}$ P.S Anindita \\ ${ }^{2}$ Paulina N. Gunawan
${ }^{1}$ Mahasiswa Program Studi Pendidikan Dokter Gigi Fakultas Kedokteran
Universitas Sam Ratulangi Manado
${ }^{2}$ Program Studi Pendidikan Dokter Gigi Fakultas Kedokteran
Universitas Sam Ratulangi Manado
Email: vigni.laguhi@yahoo.com

\begin{abstract}
Abstrak: Maloklusi adalah suatu bentuk oklusi yang menyimpang dari bentuk standar yang diterima sebagai bentuk normal dan di Indonesia prevalensinya masih cukup tinggi. Salah satu cara mengidentifikasi maloklusi dan menilai keparahan maloklusi tersebut menggunakan Indeks Handiccaping Assessment Record (HMAR). Penelitian ini bertujuan untuk mengetahui gambaran maloklusi pasien RSGM Unsrat menggunakan Indeks HMAR. Penelitian ini bersifat deskriptif dan dilakukan di RSGM Unsrat Manado. Subjek penelitian berjumlah 34 model studi pasien. Penilaian maloklusi diperoleh dengan pemeriksaan pada sampel penelitian berdasarkan indeks HMAR meliputi penyimpangan gigi dalam satu rahang, kelainan hubungan gigi kedua rahang dalam keadaan oklusi, dan kelainan dentofasial. Hasil penelitian pada penyimpangan gigi dalam satu rahang menunjukkan persentase tertinggi pada kehilangan gigi. Kelainan hubungan gigi kedua rahang dalam keadaan oklusi menunjukkan di regio anterior persentase tertinggi berupa jarak gigit berlebih dan diregio posterior tertinggi berupa gigi kaninus lebih ke distal. Kelainan dentofasial menunjukkan persentase tertinggi berupa palatal bite. Hasil penelitian tingkat keparahan maloklusi berdasarkan indeks HMAR menunjukkan persentase tertinggi pada maloklusi berat sangat memerlukan perawatan.
\end{abstract}

Kata kunci: Maloklusi, Indeks Handicapping Malocclusion Assessment Record

\begin{abstract}
Malocclusions is a form of occlusions that deviates from the standard form which is accepted as a normal form and in Indonesia, the prevelence is still high enough. One of the ways to identify and assess the severity of malocclusions is using the Handicapping Malocclusion Assessment Record Index (HMAR). This study aims to describe the malocclusions patients of RSGM Unsrat using the HMAR index.

This is a descriptive study conducted at the RSGM Unsrat Manado. Research subjects which totaled 34 patient study models. Malocclusions assessment obtained by examination of the study sample according to HMAR index include the tooth defect in one jaw, the second jaw teeth abnormalities relationship in a state of occlusions, and dentofasial defect. Result of research on the teeth in one jaw irregularities showed the highest percentage of tooth loss. Abnormal jaw relations in a state of second gear in the region of the anterior occlusion showed the highest percentage in the form of excessive biting distance and in the posterior region of highest form of canines more distally. Dentofacial abnormalities showed the highest percentage in the form of palatal bite. Research malocclusions severity based on HMAR index showed the highest percentage of severe malocclusions are in need of care.
\end{abstract}

Keywords: Malocclusions, Handicapping Malocclusion Assessment Record Index

Kehidupan manusia, gigi dan mulut merupakan investasi bagi kesehatan sepanjang hidup. Gigi berperan pada proses pengunyahan, berbicara dan penampilan. Berbagai penyakit maupun kelainan gigi dan mulut dapat memengaruhi berbagai fungsi rongga mulut. Salah satunya adalah kelainan susunan gigi atau disebut maloklusi. ${ }^{1}$

Maloklusi adalah suatu bentuk oklusi yang menyimpang dari bentuk standar yang diterima sebagai bentuk normal. Oklusi dikatakan normal jika susunan gigi dalam 
lengkung teratur baik serta terdapat hubungan yang harmonis antara gigi atas dan gigi bawah. Maloklusi sebenarnya bukan suatu penyakit tetapi bila tidak dirawat dapat menimbulkan gangguan pada fungsi pengunyahan, penelanan, bicara, dan keserasian wajah, yang berakibat pada ganguan fisik maupun mental. ${ }^{2}$

Berdasarkan laporan hasil Riset Kesehatan Dasar (Riskesdas) Nasional tahun 2013, sebanyak 14 provinsi mengalami masalah gigi dan mulut yaitu $25,9 \%{ }^{3}$ Prevalensi maloklusi di Indonesia masih sangat tinggi sekitar $80 \%$ dari jumlah penduduk, dan merupakan salah satu masalah kesehatan gigi dan mulut yang cukup besar, hal ini ditambah dengan tingkat kesadaran perawatan gigi yang masih rendah dan kebiasaan buruk seperti mengisap ibu jari atau benda-benda lain, karena jumlah dan keparahan maloklusi akan terus meningkat maka maloklusi seharusnya dicegah ataupun ditangani. Penelitian mengenai maloklusi tidak hanya membantu dalam rencana perawatan ortodontik tetapi mengevaluasi pelayanan kesehatan. $^{4}$

Penelitian yang dilakukan oleh Rosani pada pasien ortodontik Rumah Sakit Gigi dan Mulut Fakultas Kedokteran Gigi Universitas Hasanudin (RSGM UNHAS) menunjukkan $40 \%$ yang mengalami maloklusi. Penelitian dilakukan pada siswa Sekolah Menengah Pertama (SMP) di kecamatan Malalayang oleh Astuti tahun 2011 yang mengalami maloklusi yaitu 60,2\% dan yang mengalami oklusi normal 2,2\%.

Penilaian keparahan suatu maloklusi dilakukan dengan indeks maloklusi. Salah satu Indeks untuk mengukur keadaan maloklusi yaitu Handicapping Malocclusion Assessment Record (HMAR) yang diperkenalkan oleh Salzmann pada tahun 1968. Indeks HMAR secara kuantitatif dan objektif memberikan penilaian terhadap ciriciri oklusi dan cara menentukan prioritas perawatan ortodonti menurut keparahan maloklusi yang dapat dilihat dari besarnya skor yang tercatat pada lembar isian. Indeks HMAR ini digunakan untuk mengukur kelainan gigi pada satu rahang, kelainan hubungan kedua rahang dalam keadaan oklusi dan kelainan dentofasial. Penilaian dapat dilakukan pada model gigi atau di dalam mulut. Penilaian Indeks HMAR tidak memerlukan alat khusus atau rumit, dibandingkan dengan indeks lain. ${ }^{7}$

Rumah Sakit Gigi dan Mulut Universitas Sam Ratulangi Manado merupakan tempat para mahasiswa profesi melanjutkan studinya. RSGM Unsrat Manado belum memiliki data statistik tentang gambaran maloklusi berdasarkan Indeks HMAR dan belum pernah dilakukan penelitian tentang gambaran maloklusi menggunakan model studi pasien ortodontik. Berdasarkan pemikiran tersebut, penulis tertarik untuk melakukan penelitian gambaran maloklusi pasien berdasarkan Indeks HMAR di RSGM Unsrat Manado.

\section{BAHAN DAN METODE}

Jenis penelitian yang digunakan adalah deskriptif. Penelitian telah dilakukan pada bulan Maret dan Mei 2014 di RSGM Unsrat Manado. Populasi pada penelitian ini ialah model studi sebelum perawatan ortodontik di RSGM Unsrat Manado tahun 2012 dengan kriteria sampel yang digunakan yaitu total sampel yang memenuhi kriteria inklusi yaitu 34 model studi awal rahang atas dan rahang bawah yang tidak mengalami kerusakan dan mempunyai gigi geligi permanen.

Data primer berupa data maloklusi berdasarkan Indeks HMAR. Penilaian maloklusi dilakukan dengan pemeriksaan secara langsung pada model studi yang memenuhi kriteria inklusi. Setelah itu model studi, vernier caliper dan alat tulis dipersiapkan peneliti. Kemudian penyimpangan yang di ukur yaitu berupa gigi hilang, gigi berjejal, gigi rotasi dan gigi renggang dalam satu rahang. Selanjutnya dilakukan pengukuran hubungan gigi kedua rahang dalam keadaan oklusi yaitu dengan cara model studi di oklusikan pada posisi oklusi sentrik untuk mengukur adanya jarak gigit berlebih, tumpang gigit berlebih, gigitan silang dan gigitan terbuka. Kelainan dentofasial dilihat dari adanya gangguan 
Laguhi, Anindita, Gunawan; Gambaran Maloklusi dengan Menggunakan HMAR...

bicara dan palatal bite. Data sekunder yang berkaitan dengan identitas pasien sebelum melakukan perawatan yang tertulis pada rekam medik pasien.

\section{HASIL PENELITIAN}

Pemeriksaan maloklusi berupa penyimpangan gigi dalam satu rahang meliputi pemeriksaan kehilangan gigi, gigi berjejal, gigi rotasi, dan gigi renggang. Distribusi penyimpangan gigi dalam satu rahang gigi dapat dibedakan pada model studi rahang atas dan rahang bawah (Tabel 1).

Data pada Tabel 1 menunjukkan bahwa penyimpangan gigi dalam satu rahang yang terbanyak berupa kehilangan gigi dan lebih banyak ditemukan pada rahang bawah sebanyak 52,9\%. Gigi berjejal lebih banyak ditemukan di rahang bawah yaitu 32,3\%, gigi rotasi ditemukan lebih banyak di rahang bawah yaitu 42,9\%, dan gigi renggang ditemukan lebih banyak pada rahang atas yaitu $41,1 \%$.

Tabel 1. Distribusi penyimpangan gigi dalam satu rahang

\begin{tabular}{lcccccccccc}
\hline & \multicolumn{3}{c}{ Rahang atas } & \multicolumn{3}{c}{ Rahang bawah } & \multicolumn{2}{c}{ Total } \\
& \multicolumn{2}{c}{ Ada } & \multicolumn{2}{c}{ Tidak } & \multicolumn{2}{c}{ Ada } & \multicolumn{2}{c}{ Tidak } & & \\
& $\mathrm{n}$ & $\%$ & $\mathrm{n}$ & $\%$ & $\mathrm{n}$ & $\%$ & $\mathrm{n}$ & $\%$ & $\mathrm{n}$ & $\%$ \\
\hline $\begin{array}{l}\text { Kehilangan } \\
\text { gigi }\end{array}$ & 7 & 20,5 & 27 & 79,5 & 18 & 52,9 & 16 & 47,1 & 34 & 100 \\
Gigi berjejal & 7 & 20,5 & 23 & 67,7 & 11 & 32,3 & 27 & 79,5 & 34 & 100 \\
Gigi rotasi & 13 & 38,3 & 21 & 61,7 & 16 & 42,9 & 18 & 57,1 & 34 & 100 \\
Gigi renggang & 14 & 41,1 & 20 & 58,9 & 11 & 32,3 & 23 & 67,1 & 34 & 100 \\
\hline
\end{tabular}

Tabel 2. Distribusi kelainan hubungan gigi kedua rahang dalam keadaan oklusi

\begin{tabular}{lcccccccc}
\hline & \multicolumn{2}{c}{ Jarak gigit berlebih } & \multicolumn{2}{c}{ Tumpang gigit berlebih } & \multicolumn{2}{c}{ Gigitan silang } & \multicolumn{2}{c}{ Gigitan terbuka } \\
& $\mathrm{n}$ & $\%$ & $\mathrm{n}$ & $\%$ & $\mathrm{n}$ & $\%$ & $\mathrm{n}$ & $\%$ \\
\hline Ada & 20 & 58,9 & 16 & 47,1 & 2 & 5,9 & 3 & 8,9 \\
Tidak & 14 & 41,1 & 18 & 52,9 & 32 & 94,1 & 31 & 91,9 \\
Total & 34 & 100 & 34 & 100 & 34 & 100 & 34 & 100 \\
\hline
\end{tabular}

Tabel 3. Distribusi subjek penelitian pada kelainan anteroposterior

\begin{tabular}{lcccccc}
\hline & \multicolumn{3}{c}{ Kelainan anterior posterior } & \multicolumn{2}{c}{ Total } \\
& \multicolumn{2}{c}{ Mesial } & \multicolumn{2}{c}{ Distal } & n & $\%$ \\
\hline Kaninus & 4 & 11,7 & 6 & 17,7 & 10 & 29,4 \\
Premolar 1 & 2 & 5,9 & 1 & 2,9 & 3 & 8,8 \\
Premolar 2 & 4 & 11,7 & 2 & 5,9 & 6 & 17,6 \\
Molar 1 & 4 & 11,7 & 3 & 8,9 & 7 & 20,6 \\
Molar 2 & 5 & 14,7 & 3 & 8,9 & 8 & 23,6 \\
Total & 19 & 55,7 & 15 & 53,3 & 34 & 100 \\
\hline
\end{tabular}

Pemeriksaan maloklusi berupa kelainan hubungan gigi kedua rahang dalam keadaan oklusi meliputi jarak gigit berlebih, tumpang gigit berlebih, gigitan silang, gigitan terbuka di regio anterior dan kelainan anterior posterior (Tabel 2).

Data pada Tabel 2 menunjukkan maloklusi terbanyak berupa jarak gigit berlebih yaitu $58,9 \%$, tumpang gigit berlebih sebanyak $47,1 \%$, dan hanya 5,9\% memiliki 
gigitan silang dan sebanyak 8,9\% memiliki gigitan terbuka.

Distribusi kelainan anteriorposterior pada hubungan gigi kedua rahang dalam keadaan oklusi (Tabel 3).

Data pada Tabel 3 menunjukkan distribusi kelainan anteroposterior pada model studi ditemukan yang paling banyak berupa gigi kaninus lebih ke distal yaitu 17,7\%.

Hasil pemeriksaan kelainan dentofasial meliputi gangguan fungsi bicara, dan palatal bite (Tabel 4).

Tabel 4. Distribusi kelainan dentofasial

\begin{tabular}{lcccccc}
\hline & \multicolumn{6}{c}{ Kelainan dentofasial } \\
& \multicolumn{2}{c}{ Ada } & \multicolumn{2}{c}{ Tidak } & \multicolumn{2}{c}{ Total } \\
& $\mathrm{n}$ & $\%$ & $\mathrm{n}$ & $\%$ & $\mathrm{n}$ & $\%$ \\
\hline $\begin{array}{l}\text { Gangguan } \\
\text { bicara }\end{array}$ & 0 & 0 & 34 & 100 & 34 & 100 \\
Palatal bite & 1 & 2,9 & 33 & 97,1 & 34 & 100 \\
\hline
\end{tabular}

Data pada Tabel 4 menunjukkan tidak dijumpai gangguan bicara dan hanya ditemukan satu kelainan dentofasial berupa palatal bite yaitu 2,9\%.

Distribusi tingkat keparahan maloklusi dikategorikan berdasarkan Indeks HMAR dapat dilihat pada (Tabel 5).

Tabel 5. Distribusi skor keparahan maloklusi

\begin{tabular}{lcc}
\hline Kriteria keparahan maloklusi & \multicolumn{2}{c}{ Jumlah } \\
& $\mathrm{n}$ & $\%$ \\
\hline $\begin{array}{l}\text { Variasi oklusi normal } \\
\text { Maloklusi ringan, tidak perlu } \\
\text { perawatan }\end{array}$ & 3 & 0 \\
$\begin{array}{l}\text { Maloklusi ringan, memerlukan } \\
\text { perawatan }\end{array}$ & 9 & 26,5 \\
$\begin{array}{l}\text { Maloklusi berat, memerlukan } \\
\text { perawatan }\end{array}$ & 10 & 29,4 \\
$\begin{array}{l}\text { Maloklusi berat, sangat } \\
\text { memerlukan perawatan }\end{array}$ & 12 & 35,3 \\
Total & 34 & 100 \\
\hline
\end{tabular}

Data pada Tabel 5 menunjukkan tingkat keparahan maloklusi berdasarkan Indeks HMAR semakin meningkat dari maloklusi ringan tidak memerlukan perawatan sampai maloklusi berat sangat memerlukan perawatan. Hasil tertinggi pada malokluksi berat sangat memerlukan perawatan ditemukan 35,3\%.

\section{BAHASAN}

Distribusi hasil penelitian terdiri dari penyimpangan gigi dalam satu rahang, kelainan hubungan gigi kedua rahang dalam keadaan oklusi, kelaianan anterioposterior dan kelainan dentofasial.

Distribusi gigi yang hilang pada penelitian ini lebih banyak pada rahang bawah. Hasil penelitian ini serupa dengan hasil penelitian yang dilakukan oleh Dewi pada remaja SMU di kota Medan tahun 2007 yang hasilnya menunjukkan gigi yang hilang ditemukan lebih banyak pada rahang bawah. ${ }^{1}$ Kehilangan gigi dikarenakan berbagai penyebab antara lain dapat di sebabkan oleh karies, penyakit periodontal, trauma dan gigi telah dicabut oleh dokter gigi. ${ }^{8}$ Sebagian besar gigi yang hilang pada penelitian ini dijumpai lebih banyak pada rahang bawah yaitu pada gigi molar. Hal ini disebabkan karena merupakan daerah yang rentan terhadap karies pada permukaaan oklusal gigi molar permanen rahang bawah. Terdapat juga sebagian gigi molar tiga tidak tumbuhnya benih gigi permanen. ${ }^{9}$

Hasil penelitian gigi berjejal lebih banyak ditemukan pada rahang bawah dari pada rahang atas. Hasil penelitian ini serupa dengan Isnaniah di Klinik Terpadu Fakultas Kedokteran Gigi Universitas Padjadjaran tahun 2013 yang hasilnya menunjukkan persentase gigi berjejal sebanyak 50\% di segmen anterior rahang bawah. ${ }^{10}$ Bhalajhi menjelaskan gigi berjejal terjadi akibat tidak harmonisnya ukuran gigi dan panjang lengkung rahang misalnya ukuran gigi yang terlalu besar, lengkung rahang yang terlalu pendek atau jumlah gigi lebih dari normal. ${ }^{11}$ Gigi berjejal pada rahang bawah lebih besar disebabkan oleh adanya tekanan dari jaringan lunak bibir dan posisi serta volume lidah, gigi berlebih, tanggalnya gigi tetap, dan bentuk gigi tetap tidak normal. ${ }^{12}$

Hasil penelitian gigi rotasi lebih banyak ditemukan pada rahang bawah. Hasil penelitian ini serupa dengan penelitian Rambak yang hasilnya menunjukkan 
persentase gigi rotasi paling banyak pada rahang bawah. ${ }^{13}$ Rotasi gigi merupakan salah satu bagian dari maloklusi gigi. Faktor penyebab terjadi gigi rotasi yaitu ketidakteraturan posisi gigi, bentuk gigi permanen yang tidak normal. Gigi rotasi pada lengkung rahang disebabkan adanya ruang akibat kehilangan gigi disebelah gigi tersebut sehingga mengakibatkan gigi tersebut bergerak menyimpang dari sumbunya, keadaan ini sesuai hasil gigi yang hilang . Rotasi gigi terjadi ketika gigi berputar di sekitar pusat resistensinya. ${ }^{14}$

Hasil penelitian gigi renggang yang ditemukan dalam penelitian ini sebagian besar berupa central diastema. Hasil penelitian oleh Gatot di Jakarta tahun 2011 pada siswa remaja yang hasilnya menunjukkan persentase terbanyak berupa gigi renggang berupa central diastema. ${ }^{15}$ Central diastema dapat disebabkan oleh perlekatan frenulum labialis yang tinggi sehingga mengakibatkan adanya jarak di antara insisivus kanan dan kiri pada rahang atas dan keadaan patologi salah satunya yaitu gigi supernumerary dan sebuah penelitian oleh Foster bahwa dari 100 anak yang diteliti $33 \%$ anak yang memiliki gigi renggang pada gigi insisivus. ${ }^{11,21}$ Gigi renggang dapat disebabkan oleh agenesis insisivus lateralis, impaksi gigi kaninus, microdontia. Agenesis bisa mengubah oklusi dan posisi gigi melalui kelainan terhadap bentuk gigi dan pertumbuhan rahang. Jika gigi permanen agenesis, susunan gigi menjadi renggang dan gigi yang masih ada menjadi malposisi. ${ }^{16}$

Distribusi maloklusi pada subjek penelitian pada kategori kelainan hubungan gigi kedua rahang dalam keadaan oklusi pada regio anterior menunjukkan jumlah tertinggi berupa jarak gigit berlebih. Hasil penelitian ini serupa dengan hasil penelitian yang dilakukan oleh Rosani di RSGM UNHAS Makasar tahun 2011 yang juga menunjukkan persentase tertinggi berupa jarak gigit berlebih. ${ }^{4}$ Jarak gigit berlebih dapat dipengaruhi oleh keturanan, mendorong lidah ke depan, serta bernafas melalui mulut. ${ }^{17}$ Jarak gigit berlebih yang sangat besar pada $72 \%$ anak keadaan ini disebabkan karena kebiasaan buruk menghisap ibu jari dapat menyebabkan potrusif gigi insisivus permanen rahang atas dan gigi insisivus permanen rahang bawah linguoversi. $^{12}$

Berdasarkan hasil penelitian ini, distribusi tumpang gigit berlebih tidak jauh berbeda dengan jarak gigit berlebih pada kelainan gigi kedua rahang dalam keadaan oklusi. Hasil penelitian ini serupa dengan hasil penelitian Astuti di kecamatan Manado pada siswa SMP tahun 2011 juga menunjukkan persentase tumpang gigit berlebih yang tidak jauh berbeda dengan dengan jarak gigit berlebih. ${ }^{6}$ Tumpang gigit berlebih dapat disebabkan oleh beberapa kemungkinan antara lain supraoklusi gigi anterior, infraklusi gigi posterior, atau kondisi keduanya.

Gigitan silang dan gigitan terbuka di regio anterior ditemukan paling sedikit jumlahnya dalam penelitian ini. Hasil penelitian ini juga serupa dengan hasil penelitian Rambak pada mahasiswa PSPDG Unsrat Manado tahun 2012 yang juga menunjukkan persentase paling sedikit berupa gigitan silang dan gigitan terbuka anterior. ${ }^{13}$ Gigitan silang dapat disebabkan oleh posisi gigi anterior rahang atas yang lebih ke lingual dari pada gigi anterior rahang bawah. Kebiasaan buruk seperti bertopang dagu satu sisi dapat menyebabkan gigitan silang. ${ }^{18}$ Gigitan terbuka anterior dapat disebabkan oleh lengkung gigi rahang atas yang sempit, gigi anterior inklinasi ke depan, gigi posterior supraoklusi, dapat juga disebabkan oleh faktor genetik dan kebiasaan buruk. $^{19}$

Distribusi maloklusi pada subjek penelitian berdasarkan hasil pemeriksaan kelainan hubungan gigi kedua rahang dalam keadaan oklusi diregio posterior persentase tertinggi pada gigi kaninus lebih ke arah distal. Hasil penelitian ini sedikit berbeda dengan hasil penelitian yang dilakukan oleh Rosani pada pasien ortodontik di RSGM UNHAS tahun 2012 yang mendapatkan gigi kaninus yang bergeser ke arah mesial. ${ }^{5}$ Salah satu penyebabnya yaitu gigi insisivus dua rahang atas tidak erupsi sehingga gigi kaninus atas cenderung bergerak ke mesial 
yang menyebabkan gigi kaninus rahang bawah lebih ke distal. ${ }^{20}$

Distribusi maloklusi pada subjek penelitian berdasarkan hasil pemeriksaan menunjukkan hanya memiliki satu kelainan dentofasial berupa palatal bite. Hasil penelitian ini serupa dengan penelitian yang dilakukan oleh Rezeki tahun 2007 di RSGM UI hanya menemukan satu kelainan dentofasial yaitu pada palatal bite pasien yang mengalami oklusi traumatik. ${ }^{21}$ Keadaan ini dapat disebabkan oleh adanya jarak gigit dan tumpang gigit yang berlebih sehingga bibir bawah terletak di palatal gigi insisivus rahang atas. ${ }^{22}$

Distribusi maloklusi berat sangat memerlukan perawatan merupakan jumlah tertinggi dari semua tingkat keparahan maloklusi yang diteliti. Hasil penelitian ini berbeda dengan hasil penelitian yang dilakukan oleh Rambak tahun 2012 yaitu terendah pada kategori maloklusi berat sangat memerlukan perawatan. ${ }^{13}$ Hal ini dapat disebabkan oleh perbedaan tingkat pengetahuan, sosial ekonomi dan sikap dari subjek penelitian yang diteliti. Penelitian yang dilakukan oleh Rambak pada mahasiswa Kedokteran Gigi Unsrat Manado sudah memilki tingkat pengetahuan dan sikap yang baik tentang perawatan maloklusi. Penelitian ini dilakukan pada pasien yang datang di RSGM Unsrat Manado belum memiliki pengetahuan yang baik tentang perawatan maloklusi dan juga tidak didukung dengan sikap untuk melakukan suatu tindakan perawatan maloklusi.

\section{SIMPULAN}

Tingkat keparahanan maloklusi berdasarkan Indeks HMAR persentase terbanyak yaitu pada kategori maloklusi berat yang sangat memerlukan perawatan. Penyimpangan gigi dalam satu rahang di regio anterior dan posterior terbanyak berupa kehilangan gigi dan gigi rotasi. Kelainan hubungan gigi kedua rahang dalam keadaan oklusi di regio anterior terbanyak pada kasus jarak gigit dan terendah pada kasus gigitan silang. Kelainan anteroposterior terbanyak yaitu pada kaninus lebih ke distal. Kelainan dentofasial terdapat hanya satu kelainan yaitu berupa palatal bite.

\section{SARAN}

Masih diperlukan adanya penyuluhan kepada masyarakat secara berkala oleh klinisi dalam rangka mengoptimalkan pelayanan pencegahan maloklusi. Dapat dilakukan penelitian lebih lanjut mengenai gambaran maloklusi berdasarkan etiologi maloklusi.

\section{DAFTAR PUSTAKA}

1. Dewi O. Analisis hubungan maloklusi dengan kualitas hidup pada remaja SMU Kota Medan tahun 2007. [online] 2013 [Serial 2013 Aug 22]. Available from: URL:http//repository.usu.ac.id//699/1/08E0 0229.pdf.

2. Susanto C. Need and demand serta akibat dari maloklusi pada siswa SMU Negeri 1 Binjai. [online] 2010 [Serial 2013 june 8]. Available from:URL:http//repository.usu.ac.id/bitstrea m/123456789/18207/7/chapter\%201.pdf

3. Badan Penelitian dan Pengembangan Kesehatan. Departemen Kesehatan RI. Laporan hasil riset kesehatan dasar (Riskesdas) Nasional 2013. Jakarta.2013.h.111-112.

4. Budiyanti EA. Pengaruh perilaku ibu dan pola keluarga pada kebiasaan menghisap jari pada anak, dikaitkan dengan status oklusi gigi sulung. [online] 2013 [Serial 2013 Aug 22]. Available from: URL:http//eperints. lib.ui.ac.id//16709/1/91278\%2Dpengaruh\% perilaku\%2Dfull

5. Rosani WF. Penilaian maloklusi berdasarkan handicaping malocclusion assessment record pada pasien ortodontik di BP-RSGM FKG Unhas.[ online ] 2010 [ Serial 2013 june8].Available from: URL: http//respository.unhas.ac.id/bitstream/handl e/abstrak.doc

6. Astuti TY. Gambaran maloklusi pada siswa sekolah menengah pertama di Kecamatan Malalayang. Dentire Journal. 2012 juni (1) 48.

7. Harty FJ. Ogston R. Kamus kedokteran gigi. Jakarta: Penerbit buku kedokteran(EGC); 1995. h.189. 
8. Thio ML. Pola kehilangan gigi dan kebutuhan perawatan gigi tiruan sebagian lepasan di Kelurahan Meras Kecamatan Bunaken. Skripsi. Manado: FKG Unsrat 2013.h.5-6.

9. Joyston S. Dasar -dasar karies. $3^{\text {th }}$ ed. Jakarta: Penerbit buku kedokteran (EGC) ;1992.h.9-13.

10. Isnaniah M. Distribusi maloklusi di klinik Terpadu Fakultas Kedokteran Gigi Universitas Padjajaran. Dentika Dental journal 2013;7: 67-68.

11. Iswary HS. Gigi supernumerary dan perawatan ortodonsi. Dental journal FKG Prof DR Moestopo 2013; 1(1):37-38.

12. Salzman JA. Handicaping malocclusion assessment to establish treatment priority. Philadelphia: Lipincott company; 1968.p.749-65.

13. Iswary HS. Gigi supernumerary dan perawatan ortodonsi. Dental journal FKG Prof DR Moestopo 2013; 1(1):37-38.

14. Rambak PD. Gambaran maloklusi berdasarkan indeks handiccingp assessment record (HMAR) pada mahasiswa PSKG Unsrat Manado angkatan 2008. Dentire journal 2012:1(1):35. Albar F. Pengaruh rotasi gigi terhadap indikasi karies. Skripsi, Makasar: FKG UNHAS, 2014.h.16-17.

15. Albar F. Pengaruh rotasi gigi terhadap indikasi karies. Skripsi, Makasar: FKG UNHAS, 2014.h.16-17.

16. Wijanarko GA. Prevalensi maloklusi pada remaja usia 124 tahun pada Sekolah
Menengah Pertama di Jakarta.Skripsi, jakarta: FKG UI, 2014.h.1-2.

17. Aisyah. Tingkat prevalensi kebiasaan buruk pada anak prasekolah di Kota Makasar. [online] 2011 [Serial 2013 june 9] Available from:URL:

http://repository.unhas.ac.id/bitstream/BAB \%201\%2011\%2011.doc

18. Widyanti R, Anandita R. Penatalaksanaan kasus maloklusi dengan agenesis insisif lateral atas dan premolar dua bawah pada periode bercampur. Indonesia journal of dentistry 2009; 16(1):18-24.

19. Indiarti SI. Posterior bite plane with simple spring for correction anterior crossbite in 8 years old. Dent J 2010; 18(1) 4.

20. Iswary HS. Relaps dan pencegahan dalam ortodonti. Dent journal [serial online] 2012 [ cited April 13 2014]. Available from:http//journl.unair.ac.idpdf.

21. Al-Daoody AD. Finger sucking habit: Prevalence, countributing factors and effect on occlusion. Al-Rafidain dent $\mathrm{J}$ [ serial online] 2004 [ cited April 13 2014]. Available from:http//rafidaindentj.net/pdf/2004,2/135 \%20-142.pdf

22. Rezeki A. Kerusakan jaringan periodonsium pada gigi anterior yang disebabkan oleh oklusi tramautik pada peserta pasien PPDGS periodonsia FKG UI 2005. Skripsi, Jakarta:FKG UI, 2011.h.3-4. 